\title{
Complications of Robotic Surgery in Urology: Our Experience of 342 Procedures Including the Learning Curve
}

\author{
Ürolojide Robotik Cerrahi Komplikasyonları: Öğrenme Eğrisini de Kapsayan 342 Hastalık \\ Deneyimimiz
}

\author{
(D) Ekrem İslamoğlu, (D) Hakan Anıl, (D) Kaan Karamık, (D) Yasin Aktaş, (D) Ali Yıldız, (D) Mutlu Ateş, (D) Murat Savaş \\ University of Health Sciences, Antalya Training and Research Hospital, Clinic of Urology, Antalya, Turkiye
}

\section{What's known on the subject? and What does the study add?}

Like in every new technique, robotic surgery also has a learning curve and in order to reduce complications, surgeons need to approach each case carefully until they reach a certain level of experience.

\begin{abstract}
Objective: The aim of this study is to analyze the complications of all robot-assisted surgeries performed in our clinic and to investigate the effect of the learning curve on complications occurred.

Materials and Methods: Data on a total of 342 robotic surgeries performed in our clinic between March 2015 and February 2018 was retrospectively analyzed. Two surgeons, who performed the surgery, were experienced in urological laparoscopic procedures. Intraoperative and postoperative complications were evaluated. According to the experience of robotic surgery, the complications were divided into two groups as those occurred in the first 18 months (March 2015-August 2016) and in the second 18 months (September 2016-February 2018). The complications were classified according to the Clavien-Dindo classification.

Results: A total of 32 complications occurred in 31 of 342 patients undergoing robot-assisted surgery. The overall complication rate was $9.4 \%$. The number of minor complications was 20 (62.5\%), and the number of major complications was 12 (37.5\%). Among all, 6.2\% were intraoperative complications, $62.5 \%$ were postoperative complications, and $31.3 \%$ were medical complications. It was observed that the number of complications was plateaued after August 2016 and there was a statistically significant difference between the first and the second 18 months ( $<<0.05$ ).

Conclusion: Laparoscopic surgery experience alone is not enough to reduce complications in robot-assisted surgery and learning continues with every case. An experienced surgeon and robotic surgery team are needed for complex robotic surgeries.

Keywords: Complication, Robotic surgery, Urology

\section{Öz}

Amaç: Bu çalışmanın amacı kliniğimizde uygulanan tüm robot yardımlı ameliyatlardaki komplikasyonları analiz etmek ve öğrenme eğrisinin komplikasyon gelişimi üzerine etkisini araştırmaktır.

Gereç ve Yöntem: Mart 2015 ile Şubat 2018 arasında kliniğimizde uygulanan toplam 342 robotik cerrahinin verileri analiz edildi. İki cerrah da ürolojik laparoskopik cerrahide deneyimliydi. İntraoperatif ve postoperatif komplikasyonlar değerlendirildi. Robotik cerrahi deneyimine göre ilk 18 ayda (Mart 2015-Ağustos 2016) ve ikinci 18 ayda (Eylül 2016-Şubat 2018) karşılaşılan komplikasyonlar olarak iki gruba ayrıldı. Komplikasyonlar Clavien-Dindo sınıflamasına göre kategorize edildi.

Bulgular: Robotik cerrahi yapılan 342 hastanın 31'inde, toplam olarak 32 komplikasyon gelişti. Toplam komplikasyon oranı \%9,4 idi. Minör komplikasyonların sayısı $20(\% 62,5)$, majör komplikasyonların sayısı $12(\% 37,5)$ idi. Tüm komplikasyonların \%6,2'sini intraoperatif komplikasyonlar, \%62,5'ini postoperatif komplikasyonlar, \%31,3'ünü medikal komplikasyonlar oluşturmaktaydı. Komplikasyon sayılarının Ağustos 2016'dan sonra plato çizdiği görüldü ve ilk 18 ay ile son 18 ay arasında istatistiksel olarak anlamlı fark bulundu $(p<0,05)$.
\end{abstract}

Correspondence: Ekrem İslamoğlu MD, University of Health Sciences, Antalya Training and Research Hospital, Clinic of Urology, Antalya, Turkiye E-mail: meislamoglu@gmail.com ORCID-ID: orcid.org/0000-0003-0693-0666

Received: 20.06.2018 Accepted: 20.07.2018

Cite this article as: İslamoğlu E, Anıl H, Karamık K, Aktaş Y, Yıldız A, Ateş M, Savaş M. Complications of Robotic Surgery in Urology: Our Experience of 342 Procedures Including the Learning Curve. J Urol Surg 2018;5(4):194-198. 
Sonuç: Laparoskopik cerrahi tecrübesi, robotik cerrahideki komplikasyonları azaltmakta tek başına yeterli değildir ve öğrenme her olguyla birlikte devam eder. Komplike robotik cerrahiler için, deneyimli bir cerrah ve robotik cerrahi ekibine intiyaç duyulmaktadır.

Anahtar Kelimeler: Komplikasyon, Robotik cerrahi, Üroloji

\section{Introduction}

The reason for the development of laparoscopic surgery was to achieve similar results to open surgery but with lower morbidity and shorter recovery period. Although laparoscopic methods and auxiliary instruments were developed over the years, laparoscopic surgery remained a complex surgery with a long learning curve (1). Despite being termed as minimally-invasive, most of the laparoscopic operations performed in urology clinics are major surgeries and have a significant likelihood of complications. Robot-assisted laparoscopic surgery was introduced to urology practice in the year 2000 and became a common method within the past seventeen years (2). Contrary to two-dimensional image provided by standard laparoscopic systems, robotic systems offer 3-dimensional image and sense of depth for the surgeon. In addition, while standard laparoscopic equipments provide the surgeon a mobility in four directions, robotic systems offer a freedom of movement in six even seven directions similar to the human hand and wrist (3). Despite all these advantages, complications also occurred in robot-assisted laparoscopic surgeries and reported in the literature mainly by using Clavien-Dindo classification system. The Clavien-Dindo classification relies on the type of treatment used to handle the complication and this classification system is widely used in all surgical branches (4).

We analyzed the complications of all robot-assisted surgeries performed in our clinic and investigated the effect of the learning curve on complications occurred.

\section{Materials and Methods}

The data on 342 robotic surgeries performed in our clinic between March 2015 and February 2018 was retrospectively analyzed. The distribution of the operations was as follows: 240 radical prostatectomies, 52 partial nephrectomies, 28 radical cystectomies and urinary diversions, 6 pyeloplasties, 5 ureteroneocystostomies, 3 radical nephroureterectomies, 3 retroperitoneal lymph node dissections, 2 partial ureterectomies, 1 radical nephrectomy, 1 ureterolysis and 1 cystoplasty (Mitrofanoff). All operations were performed with a transperitoneal approach. The operations were performed by two surgeons and both surgeons were experienced in urological laparoscopic procedures. However, these surgeons had no prior robotic surgery experience, therefore, patients who were within their learning curves were also evaluated. Intraoperative and postoperative complications were recorded and they were divided into 2 groups depending on the robotic surgery experience, as complications in the first 18 months (March 2015-August 2016) and complications in the second 18 months (September 2016-February 2018).

The complications were categorized according to the ClavienDindo classification. According to this classification, grade 1 complications are the conditions that are deviated from normal postoperative course, however, do not require any endoscopic, surgical or radiological intervention and pharmacotherapy except for antiemetic, analgesic, antipyretic, diuretic or physiotherapy. Any pharmacotherapy necessity other than the medication allowed in grade 1 complications are classified as grade 2 complications. Blood transfusion, parental nutrition and infections requiring antibiotic treatment are also in this group. All complications that require surgical, endoscopic or radiologic intervention are classified as grade 3 complications. This group divided into two subgroups; interventions without general anesthesia are classified as grade $3 a$ and interventions performed under general anesthesia are classified as grade $3 \mathrm{~b}$ complications. Life-threatening conditions that require intensive care are classified as grade 4 complications and divided into subgroups; single organ failure is classified as grade 4a and multiple organ failure is classified as grade $4 b$ complications. Death of the patient is grade 5 complication. To summarize briefly; grade 1 and 2 complications are minor; grade 3, 4, and 5 complications are major complications (5).

Data and complications related to the operations were prospectively recorded in the database. Written informed consent was obtained from each patient and our study was conducted in accordance with the principles of the Helsinki Declaration. Ethics committee approval was not gained as the study also included retrospective data.

\section{Statistical Analysis}

Statistical analysis was performed using IBM SPSS Statistics software version 22.0 (IBM Corp., Armonk, NY). Differences between two groups were assessed by Student's t-test. A p value of less than 0.05 was considered statistically significant.

\section{Results}

A total of 32 complications had occurred in 31 of 342 patients. The total complication rate was $9.4 \%$. There were $20(62.5 \%)$ minor complications and $12(37.5 \%)$ major complications. 
None of the patients required switching to open surgery and no mortality was observed. The number of operations, difficulty levels and complication rates are shown in Table 1.

Intraoperative complications represented $6.2 \%$ of all complications. Ureteral injury that occurred in a radical prostatectomy procedure was repaired with ureteral stent placement and uretero-ureterostomy. In another patient, ileal injury that occurred during trocar placement was repaired intraoperatively with primary closure and robotic surgery was continued.

Postoperative complications account for $62.5 \%$ of all complications. One of the patients, who underwent radical cystectomy and neobladder surgery, was admitted to the emergency room with acute abdomen on the postoperative $25^{\text {th }}$ day. The patient was explored and neobladder rupture was detected. The blood supply of the neobladder was intact, therefore, the defect was closed with primary closure. When we explored the patient's story, we thought that the rupture could have been caused by the clean intermittent catheterization. Bladder neck contracture, which was developed in 5 patients, who underwent radical prostatectomy, was endoscopically treated. Lymphocele occurred in 6 patients and 3 of them required percutaneous drainage.
Medical complications were reported in 10 patients and represented $31.3 \%$ of all complications. Majority of these were urinary system infections. The types of all complications, incidence and Clavien-Dindo grade of the complications are shown in Table 2.

When the number of the complications was evaluated in sixmonths periods according to the surgical experience, the graphics showed a plateau after August 2016 and revealed a statistically significant difference between the first and the last 18 months $(p<0.05)$, as shown in Figure 1.

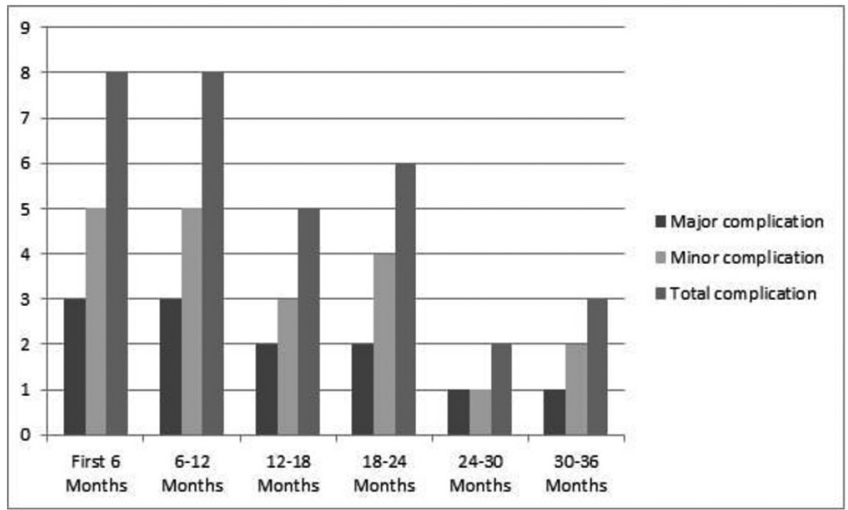

Figure 1. Distribution of the number of complications for 6 -months periods

\begin{tabular}{|c|c|c|c|c|c|c|}
\hline Robotic operations & $\begin{array}{l}\text { Technical } \\
\text { difficulty }\end{array}$ & $\begin{array}{l}\text { Number of } \\
\text { cases }\end{array}$ & $\begin{array}{l}\text { Complications, } \\
\text { n (\%) (342) }\end{array}$ & $\begin{array}{l}\text { Minor } \\
\text { complication }\end{array}$ & $\begin{array}{l}\text { Major } \\
\text { complication }\end{array}$ & $\begin{array}{l}\text { Complications for } \\
\text { individual robotic } \\
\text { cases (\%) }\end{array}$ \\
\hline Radical prostatectomy & VD & 240 & $22(6.4 \%)$ & 12 & 10 & $9.1 \%$ \\
\hline Partial nephrectomy & VD & 52 & $2(0.6 \%)$ & 2 & 0 & $3.8 \%$ \\
\hline Radical cystectomy & ED & 28 & $8(2.4 \%)$ & 6 & 2 & $28.5 \%$ \\
\hline Pyeloplasty & D & 6 & $0(0 \%)$ & 0 & 0 & $0 \%$ \\
\hline Ureteroneocystostomy & D & 5 & $0(0 \%)$ & 0 & 0 & $0 \%$ \\
\hline $\begin{array}{l}\text { Retroperitoneal lymph } \\
\text { node dissection }\end{array}$ & ED & 3 & $0(0 \%)$ & 0 & 0 & $0 \%$ \\
\hline Nephroureterectomy & D & 3 & $0(0 \%)$ & 0 & 0 & $0 \%$ \\
\hline Partial ureterectomy & D & 2 & $0(0 \%)$ & 0 & 0 & $0 \%$ \\
\hline Cystoplasty (Mitrofanoff) & VD & 1 & $0(0 \%)$ & 0 & 0 & $0 \%$ \\
\hline Radical nephrectomy & $E$ & 1 & $0(0 \%)$ & 0 & 0 & $0 \%$ \\
\hline Ureterolysis & D & 1 & $0(0 \%)$ & 0 & 0 & $0 \%$ \\
\hline Total & - & 342 & $9.4 \%$ & 20 & 12 & - \\
\hline
\end{tabular}


Table 2. Complication types, incidences and Clavien-Dindo grades

\begin{tabular}{|c|c|c|c|}
\hline Complication & Number & Percent & $\begin{array}{l}\text { Clavien- } \\
\text { Dindo } \\
\text { grade }\end{array}$ \\
\hline \multicolumn{4}{|l|}{ Intraoperative } \\
\hline Ureteral injury & 1 & 0.3 & Grade 4 \\
\hline Ileal injury & 1 & 0.3 & Grade 4 \\
\hline \multicolumn{4}{|l|}{ Postoperative } \\
\hline Bladder neck contracture & 5 & 1.5 & Grade 3 \\
\hline Lymphocele (required drainage) & 3 & 0.9 & Grade 3 \\
\hline $\begin{array}{l}\text { Lymphocele (not required } \\
\text { drainage) }\end{array}$ & 3 & 0.9 & Grade 2 \\
\hline Ileus & 2 & 0.6 & Grade 2 \\
\hline $\begin{array}{l}\text { Urethra-vesical anastomosis } \\
\text { leakage }\end{array}$ & 2 & 0.6 & Grade 2 \\
\hline Incisional hernia & 1 & 0.3 & Grade 2 \\
\hline Rupture of neobladder & 1 & 0.3 & Grade 4 \\
\hline Ureteroileal anastomosis leakage & 1 & 0.3 & Grade 3 \\
\hline Ureteral catheter migration & 1 & 0.3 & Grade 1 \\
\hline Hematoma & 1 & 0.3 & Grade 2 \\
\hline \multicolumn{4}{|l|}{ Medical } \\
\hline Urinary system infection & 6 & 1.7 & Grade 2 \\
\hline Wound infection & 1 & 0.3 & Grade 2 \\
\hline Blood transfusion & 3 & 0.9 & Grade 2 \\
\hline Total & 32 & 9.4 & - \\
\hline
\end{tabular}

\section{Discussion}

Robotic surgery has gained significant popularity within the last decade and included in the daily practice of urology $(6,7,8,9)$. Also in our country, robotic surgery is widely used and series with high number of patients are contributing to the literature $(10,11)$. In series with follow-up periods longer than five years, it was determined that there was no difference between open surgery and robotic surgery in terms of oncological results after radical prostatectomy, radical cystectomy and partial nephrectomy $(12,13,14)$.

Although complications can occur in every surgical procedure, they are more frequent in complex surgeries. While some minor complications do not affect the course of the operation and the recovery period, major complications may risk the patient's life. Therefore, prevention of complications is very important especially during the learning curve. Like in every new surgical technique, robotic surgery has its own learning curve. This learning curve was defined as a longer curve for surgeons who make a direct transition from open surgery and as a shorter curve for surgeons who have laparoscopic experience $(15,16)$.

In this study, we presented two surgeons process of transferring their laparoscopic skills to robotic surgery. It must be noted that, apart from the surgeons, a well-organized robotic surgery team also facilitates the operations. Despite all these positive factors, it took 18 months for us to plot a plateau for minor and major complications. Although the majority of the performed robotic operations were defined as "very difficult", none of the cases required switching to open surgery.

Although we began our robotic surgery experience with cases classified as "very difficult", such as partial nephrectomy and radical prostatectomy, our complication rate in the first 18 months was consistent with the literature $(17,18)$. As the surgeons gained experience, they began to perform the cases classified as "extremely difficult" and their complication rates were decreased. In all these operations, the surgeons followed a standard procedure and did not change their techniques except for minor modifications. Previous studies also showed that surgical procedures with a standard course make positive contributions to oncological results and the learning curve of the surgeons (19). We also conclude that the decreased number of complications at the end of the $18^{\text {th }}$ month was a result of following a standard surgical procedure.

In both robot-assisted and pure laparoscopic surgeries, reviewing the video records after the operation was reported to increase the surgical quality and decrease complication rates $(20,21)$. We also recorded the videos of all our operations and performed reviews and self-criticism. We believe that this also can be a factor in decreasing the complication rate.

Among all cases $70 \%$ was radical prostatectomy, $15 \%$ was partial nephrectomy, 8\% was radical cystectomy and urinary diversion. Fewer complications are expected in more frequent operations, but our complication rate in radical prostatectomy was higher than in partial nephrectomy. However, the operation-specific complication rate was higher for radical cystectomy and urinary diversion among others. This result reminds us that complex surgical procedures always carry a higher risk for complications. Therefore, it is emphasized that complex and risky procedures should be performed by experienced surgeons in reference hospitals (22).

\section{Study Limitations}

Our study has some limitations. First of all, data of a single surgeon could provide more accurate results for the determination of the learning curve. In addition, having a small number of patients and short follow-up period are other limitations.

\section{Conclusion}

Laparoscopic surgery experience alone is not enough to reduce complications in robot-assisted surgery and learning continues with every case. An experienced surgeon and robotic surgery team are needed for complex robotic surgeries. In order to 
reduce complication rates in robotic surgery, surgeons need to approach each case carefully until they reach a certain level of experience.

\section{Ethics}

Ethics Committee Approval: Ethical committee approval was not gained as the study also included retrospective data.

Informed Consent: Written informed consent forms were obtained from each patient and our study was conducted in accordance with the Helsinki Declaration.

Peer-review: Externally and internally peer-reviewed.

\section{Authorship Contributions}

Surgical and Medical Practices: E.I., M.A., M.S., Concept: E.I.., M.S., Design: E.I., M.S., Data Collection or Processing: H.A., K.K., Y.A., A.Y., Analysis or Interpretation: E.I., H.A., K.K., Literature Search: Y.A., A.Y., Writing: E.I., M.A., M.S.

Conflict of Interest: No conflict of interest was declared by the authors.

Financial Disclosure: The authors declared that this study received no financial support.

\section{References}

1. Ahlering TE, Skarecky D, Lee D, Clayman RV. Successful transfer of open surgical skills to a laparoscopic environment using a robotic interface: initial experience with laparoscopic radical prostatectomy. J Urol 2003;170:17381741.

2. Binder J, Kramer W. Robotically-assisted laparoscopic radical prostatectomy. BJU Int 2001;87:408-410.

3. Kural AR, Atuğ F. The applications of robotic surgery in urology. Turk J Urol 2010;36:248-257.

4. Clavien PA, Barkun J, de Oliveira ML, Vauthey JN, Dindo D, Schulick RD, de Santibañes E, Pekolj J, Slankamenac K, Bassi C, Graf R, Vonlanthen R, Padbury R, Cameron JL, Makuuchi M. The Clavien-Dindo classification of surgical complications: five-year experience. Ann Surg 2009;250:187-196.

5. Dindo D, Demartines N, Clavien PA. Classification of surgical complications: a new proposal with evaluation in a cohort of 6336 patients and results of a survey. Ann Surg 2004;240:205-213.

6. Kasabwala K, Patel NA, Hu JC. Review of optimal techniques for roboticassisted radical prostatectomy. Curr Opin Urol 2018;28:102-107.

7. Cadeddu JA. Re: da Vinci Xi and Si Platforms Have Equivalent Perioperative Outcomes during Robot-Assisted Partial Nephrectomy: Preliminary Experience. The Journal of Urology. 2017.

8. Nix J, Smith A, Kurpad R, Nielsen ME, Wallen EM, Pruthi RS. Prospective randomized controlled trial of robotic versus open radical cystectomy for bladder cancer: perioperative and pathologic results. Eur Urol 2010;57:196201.

9. Mufarrij PW, Woods M, Shah OD, Palese MA, Berger AD, Thomas R, Stifelman MD. Robotic dismembered pyeloplasty: a 6-year, multi-institutional experience. J Urol 2008;180:1391-1396.

10. Torer BD, Ekşi M, Kargi $T$, Sokmen D, Simsek A, Evren I, Tugcu V. Retrospective Analysis of Factors Affecting Continence after Robotic Radical Prostatectomy. JAREM 2017;7:21-26.

11. Canda AE, Özcan MF, Akbulut Z, Atmaca AF, Özdemir AT, Balbay MD. Robotic assisted laparoscopic radical cystectomy and intracorporeal studer urinary diversion. Laparosc Endosc Surg Sci 2008;15:117-124.

12. Pearce SM, Pariser JJ, Karrison T, Patel SG, Eggener SE. Comparison of Perioperative and Early Oncologic Outcomes between Open and Robotic Assisted Laparoscopic Prostatectomy in a Contemporary Population Based Cohort. J Urol 2016;196:76-81.

13. Tang JQ, Zhao Z, Liang $Y$, Liao G. Robotic-assisted versus open radical cystectomy in bladder cancer: A meta-analysis of four randomized controlled trails. Int J Med Robot 2018;14.

14. Reynolds CR, Delto JC, Paulucci DJ, Weinstein C, Badani K, Eun D, Abaza R, Porter J, Bhandari A, Hemal AK. Comparison of perioperative and functional outcomes of robotic partial nephrectomy for $\mathrm{cT} 1 \mathrm{a}$ vs $\mathrm{cT} 1 \mathrm{~b}$ renal masses. BJU Int 2017:120:842-847.

15. Doumerc N, Yuen C, Savdie R, Rahman MB, Rasiah KK, Pe Benito R, Delprado W, Matthews J, Haynes AM, Stricker PD. Should experienced open prostatic surgeons convert to robotic surgery? The real learning curve for one surgeon over 3 years. BJU Int 2010;106:378-384.

16. Wolanski P, Chabert C, Jones L, Mullavey T, Walsh S, Gianduzzo T Preliminary results of robot-assisted laparoscopic radical prostatectomy (RALP) after fellowship training and experience in laparoscopic radical prostatectomy (LRP). BJU Int 2012;110(Suppl 4):64-70.

17. Huang $X$, Wang $L$, Zheng $X$, Wang $X$. Comparison of perioperative, functional, and oncologic outcomes between standard laparoscopic and roboticassisted radical prostatectomy: a systemic review and meta-analysis. Surg Endosc 2017;31:1045-1060

18. Beauval JB, Peyronnet $B$, Benoit $T$, Cabarrou $B$, Seisen $T$, Roumiguié $M$, Pradere $B$, Khene ZE, Manach $Q$, Verhoest $G$, Thoulouzan M, Parra J, Doumerc N, Mathieu R, Vaessen C, Soulié M, Roupret M, Bensalah K. Longterm oncological outcomes after robotic partial nephrectomy for renal cell carcinoma: a prospective multicentre study. World J Urol 2018;36:897-904.

19. Zorn KC, Orvieto MA, Gong EM, Mikhail AA, Gofrit ON, Zagaja GP, Shalhav AL. Robotic radical prostatectomy learning curve of a fellowship-trained laparoscopic surgeon. J Endourol 2007;21:441-447.

20. Akin Y, Ates M, Celik O, Ucar M, Yucel S, Erdogru T. Complications of urologic laparoscopic surgery: a center surgeon's experience involving 601 procedures including the learning curve. Kaohsiung J Med Sci 2013;29:275279.

21. Touijer K, Kuroiwa K, Saranchuk JW, Hassen WA, Trabulsi EJ, Reuter VE, Guillonneau B. Quality improvement in laparoscopic radical prostatectomy for $\mathrm{pT} 2$ prostate cancer: impact of video documentation review on positive surgical margin. J Urol 2005;173:765-768.

22. Ou YC, Yang CR, Wang J, Yang CK, Cheng CL, Patel VR, Tewari AK. The learning curve for reducing complications of robotic-assisted laparoscopic radical prostatectomy by a single surgeon. BJU Int 2011;108:420-425. 